\title{
Association of Microalbuminuria with Ischemic Heart Disease, Dyslipidemia and Obesity among Diabetic Patients: Experience from 5 Year Follow up Study of 1415 Patients
}

\author{
Kamran MA Aziz* \\ Diabetology Clinic, Aseer Diabetes Center of Aseer Central Hospital, Ministry of Health, Saudi Arabia
}

*Corresponding author: Kamran MA Aziz, Diabetology Clinic, Aseer Diabetes Center of Aseer Central Hospital, Ministry of Health, P.O.Box 34, Abha, Saudi Arabia, Tel: 96672251155; Fax: 96672265301; E-mail: drkamran9999@yahoo.com

Rec date: April 25, 2014; Acc date: June 20, 2014; Pub date: June 23, 2014

Copyright: () 2014 Aziz KMA. This is an open-access article distributed under the terms of the Creative Commons Attribution License, which permits unrestricted use, distribution, and reproduction in any medium, provided the original author and source are credited.

\begin{abstract}
This paper presents a microalbuminuria, a novel marker incipient nephropathy, and its simultaneous association at cross sectional level with ischemic heart disease, dyslipidemia and obesity among diabetic patients which has not been studied together in the past. Variables BMI, HbA1c, creatinine, total cholesterol, triglycerides, LDL-C, HDL-C, microalbuminuria, systolic and diastolic blood pressure were measured and compared for the two groups with and without IHD, nephropathy, dyslipidemia and obesity. Statistically it was observed that microalbuminuria, nephropathy, hypertension, and dyslipidemia were significantly associated with the development of ischemic heart disease ( $p$-value < 0.0001 for all). Furthermore, Hypertension was significantly associated with nephropathy as obesity was associated with development of hypertension ( $p$-value $<0.0001$ for both variables). Additionally, it was demonstrated that both BMI and HDL-C were inversely and significantly correlated ( $p$-value $<0.05$ ). Both systolic and diastolic blood pressure significantly correlated with the development of microalbuminuria in this diabetic population ( $p$-value $<0.0001$ for both). Current study recommends screening diabetic patients early for microalbuminuria at primary care level, to target high BMI and $\mathrm{HbA} 1 \mathrm{c}$, early diagnosis and treatment of hypertension and dyslipidemia to prevent further diabetic complications and economic burden.
\end{abstract}

Keywords: Diabetes; Dyslipidemia; ESRD; Hypertension; IHD; Microalbuminuria; Nephropathy; Obesity; Type-1 diabetes; Type-2 diabetes

\section{Introduction}

Diabetes currently is imposing a global burden, and is the cause of morbidity and mortality with increasing prevalence worldwide. Furthermore, coronary artery disease (CAD) itself is leading cause of morbidity and mortality in most of the developed countries. The economic and social burden further intensifies in terms of cost when both diabetes and coronary heart disease coexist. Similarly it has been reported that 97 million adults in United States are overweight or obese and $75 \%$ of adult Americans have minimal physical activity or exercise. Both excessive fat and Obesity (body mass index or BMI $\geq 30$ $\mathrm{kg} / \mathrm{m}^{2}$ ), and physical inactivity predisposed to the risk of developing type-2 diabetes and other co morbid conditions such as cardiovascular complications. Diabetes mellitus is a major independent risk factor for cardiovascular disease (CVD). Increase prevalence of CVD in diabetes has been observed due to accelerated coronary atherosclerosis occurring at earlier age and advances more rapidly in diabetic population as compared to those without diabetes. Moreover, CAD is often diffuse with stenosis affecting multiple vessels; after revascularization with percutaneous transluminal coronary angioplasty (PTCA), these diabetic patients often demonstrate increased rate of restenosis. Hence it can be concluded that diabetes mellitus itself is a cardiovascular risk equivalent [1-11].

Excretion of albumin (and other proteins) in the urine is an early and progressive marker of renal dysfunction and damage in diabetes. Nephropathy still remains an important complication of diabetes, may lead to end stage renal disease (ESRD) with high incidence (40-50\%), high morbidity and mortality. Persistence albumin excretion in urine in the range $30-299 \mathrm{mg} / 24 \mathrm{~h}$ (also known as microalbuminuria) is the earliest indicator of incipient diabetic nephropathy in type- 1 and type-2 diabetic subjects, and may also lead to ESRD. The term microalbuminuria was introduced and defined in 1985 and since then it is widely accepted as an early indicator of renal damage.

Traditionally, the term "diabetic nephropathy" was defined as chronic kidney disease (CKD) resulting due to diabetes. However, recently the Diabetes and Chronic Kidney Disease work group of the National Kidney Foundation (NKF) and Kidney Disease Outcomes Quality Initiative (KDOQI) suggested that a diagnosis of CKD presumed to be caused by diabetes should be referred to as "diabetic kidney disease (DKD)" and the term "diabetic nephropathy" should be reserved for kidney disease attributed to diabetes with histopathological injury demonstrated by renal biopsy. CVD risk is doubled in diabetic patients with microalbuminuria than those without microalbuminuria. Furthermore, there is inverse relation between microalbumin and GFR; as albumin excretion in urine increases, GFR decreases and also CVD risk increases progressively. Additionally, diabetic patients who progress from microalbuminuria stage to macroalbuminuria ( $\geq 300 \mathrm{mg} / 24 \mathrm{~h}$ ) are likely to progress ESRD [12-23].

Coronary artery disease (CAD) or ischemic heart disease (IHD) is common in diabetes. Moreover, myocardial ischemia is usually silent in diabetic patients and undiagnosed IHD undoubtedly worsens the prognosis, including diabetic cardiomyopathy associated with diabetic glomerulosclerosis. Type-2 diabetic subjects have underlying insulin resistance (IR) which is in turn a risk for CVD. Furthermore, 
metabolic syndrome (or Syndrome-X) contributes to the development of insulin resistance. Patients with diabetic dyslipidemia also demonstrate underling insulin resistance (IR). Hypertension is another well-established risk factor for CVD/IHD, to the development and progression of diabetic nephropathy (DKD) and has association with IR [24-46].

Research trials have shown a positive association between impaired glycemic control (HbAlc) (hyperglycemia) and the risk of CHD (coronary heart disease) (IHD/CAD). In the UKPDS (United Kingdom Prospective Diabetes Study) have showed significant relative risk reduction of fatal or nonfatal MI (myocardial infarction) of $39 \%$ $(\mathrm{P}=0.023)$ with intensive control. Additionally, DM subjects have two to three fold higher mortality risk due to the "diabetic cardiomyopathy" that is not related to the atherosclerosis. The DIGAMI study has shown that mortality following MI can be reduced by insulin infusions in intensive care units. Meigs and Associates have shown a Longitudinal Association of Glycemia and Microalbuminuria. Similarly In the landmark Diabetes trial, DCCT, microalbuminuria was more prevalent $(13$ vs. $7 \%, \mathrm{P}<0.01)$ and $\mathrm{HbAlc}$ was higher $(9.1$ vs. $7.4 \%, \mathrm{P}<0.01)$ in the conventional treatment group as compared to the intensive insulin treatment group [47-52].

Under this background, purpose of the current study was to measure the novel screening patent, the micro-albuminria, for cardiac and renal disease and its association with lipids (dyslipidemia) and obesity in diabetic patients simultaneously, which so far has not been studied in such population. Also it was the aim to analyze other associated variables (risk factors) for the development of albuminuria with significant statistical associations.

\section{Material and Methods}

Current research is a retrospective cross sectional analytical study. For this study, data for 1415 patients were collected on initial and follow up visits at diabetology clinic of Aseer Diabetes Center of Aseer Central hospital, from January 2009 till January 2014. These patients were referred from primary health care centers to tertiary care diabetes center for annual evaluations. Known type-1 and type-2 diabetic subjects were included in the study. Pregnant subjects and children of less than 13 years of age, severe hepatic disease, and patients with ESRD or on dialysis were excluded from the study. Patients with a history of urinary tract infection, and known cases of kidney disease or nephrotic syndrome before the diagnosis of diabetes were also excluded from the study. Detailed history was taken so as to reveal past history of other co morbid conditions such as hypertension (HTN), IHD or CAD and those went for interventional cardiac procedures, PTCA and CABG (coronary artery bypass grafting). Patients with a documented history of IHD and on regular medications, PTCA, and CABG were labeled collectively as IHD and separately analyzed as "IHD profile" with other associated variables. All demographic data, including systolic and diastolic blood pressure with BMI $\left(\mathrm{kg} / \mathrm{m}^{2}\right)$, were recorded at first visit to the diabetology clinic by standardized methodology. Those with BMI $\geq 30 \mathrm{~kg} / \mathrm{m}^{2}$ were labeled obese and analyzed with selected variables in "obesity profile". All specimens of blood and urine were collected at first visit by standardized methodology and in fasting state of not less than 12 hours. All laboratory samples of blood and urine were sent to main laboratory. Subsequent data were then recorded on follow up visit and all samples request were retrieved by Natcom Hospital Information System (NATCOM HIS; National Computer System Co. Ltd), a server based HIS software [53].
LDL-C (mg/dl) was measured directly in plasma by Automated Low Density Lipoprotein (ALDL) method and HDL-C (mg/dl) was measured directly in plasma by Automated High Density Lipoprotein (AHDL) method by the Dimension clinical chemistry system and analyzer (Siemens healthcare diagnostics Inc. Newark, DE 19714, U.S.A), an in vitro diagnostic test intended for quantitative determination of low density lipoprotein cholesterol (LDL-C) and high density lipoprotein cholesterol (HDL-C). Similarly, total cholesterol and triglycerides were measured directly, by CHOL and TGL method respectively (based on enzymatic procedures), a quantitative determination by the Dimension clinical chemistry system and analyzer. Patients demonstrating elevated lipid values (LDL-C $\geq 100 \mathrm{mg} / \mathrm{dl}, \mathrm{HDL}<50 \mathrm{mg} / \mathrm{dl}$, or Triglycerides $\geq 150 \mathrm{mg} / \mathrm{dl}$ ) were labeled as dyslipidemia and analyzed as "dyslipidemia profile" with selected variables.

Serum creatinine $(\mathrm{mg} / \mathrm{dl})$ was measured by Flex reagent cartridge using the CREA method (an enzymatic biochemical reaction between creatinine and picrate in the presence of strong base $\mathrm{NaOH}$ ) used on the Dimension clinical chemistry system and analyzer (Siemens healthcare diagnostics Inc. Newark, DE 19714, U.S.A), an in vitro diagnostic test for the quantitative determination of creatinine in human serum and plasma.

For the detection of nephropathy and presence of albumin or protein in urine, fasting urine samples were analyzed for the presence of micro-albuminuria, macro-albuminuria or proteinuria. All urine samples were first analyzed for the presence of proteinuria by Quik Check ${ }^{\mathrm{m}}$ urinalysis reagent strips (ACON biotech, Co., Ltd) to rule out macro-albumin in urine. Samples demonstrating macro-albuminuria or gross proteinuria by the color change of the reagent strips were labeled as nephropathy. Samples with negative albumin or protein in urine were again screened for the presence of micro-albumin in urine by MALB method used on Dimension clinical chemistry system, in vitro diagnostic test for quantitative measurement of albumin $(\mathrm{mg} / \mathrm{L})$ in human urine by particle-enhanced turbidimetric inhibition immunoassay (PETINIA) methodology (Siemens healthcare diagnostics Inc. Newark, DE 19714, U.S.A). Micro-albumin positive samples were again labeled as micro-albumin positive and nephropathy as well. Nephropathy status was analyzed separately as "nephropathy profile" with selected variables.

HbAlc was measured by Alc Flex Reagent by the Dimension clinical chemistry system, an in vitro diagnostic assay for the quantitative determination of both percent hemoglobin Alc and total hemoglobin, based on a turbidimetric inhibition immunoassay (TINIA) principle, and the measurement of total hemoglobin is based on a modification of the alkaline hematin reaction, an NGSP certified methodology (Siemens healthcare diagnostics Inc. Newark, DE 19714, U.S.A). The percentage of total hemoglobin that is glycated was calculated and reported as \%HbAlc (in $\mathrm{g} / \mathrm{dL}$ ), and final result has been standardized to the results obtained in DCCT.

All data of the subjects were analyzed using statistical software, SPSS $^{\circ}$ version 12 for Windows (SPSS Inc, USA). All statistical tests were performed by standardized methodology. For testing normality normal Q-Q plots were used as well to assure that variables are approximately normally distributed. $\chi^{2}$ test was utilized for significant analysis between categorical variables. Student's t-test was utilized to test significant difference among different groups. While Pearson's Correlation test was used to test significant associations among continuous variable. Logistic regression was used to calculate magnitude and association of risk factors and odd ratio/adjusted odds 
Citation: Aziz KMA (2014) Association of Microalbuminuria with Ischemic Heart Disease, Dyslipidemia and Obesity among Diabetic Patients: Experience from 5 Year Follow up Study of 1415 Patients. Bioenergetics 3: 118. doi: 10.4172/2167-7662.1000118

Page 3 of 10

ratios. This study was designed to have a statistical power of $90 \%$ to detect significant changes. All p-values were two sided, and p-values less than 0.05 were considered statistically significant.

\section{Results} 1.

Demographic characteristics of diabetic patients are shown in Table

\begin{tabular}{|c|c|c|}
\hline \multicolumn{3}{|c|}{ Demographic Data of Diabetic Patients } \\
\hline \multirow{2}{*}{\begin{tabular}{|l|} 
Parameters \\
Gender
\end{tabular}} & \multicolumn{2}{|c|}{ Description with $N(\%) ;$ Totals $=1415$} \\
\hline & Male & Female \\
\hline & $890(62.9 \%)$ & $525(37.1 \%)$ \\
\hline \multirow[t]{2}{*}{ Type of Diabetes } & Type-1 & Type-2 \\
\hline & $105(7.4 \%)$ & $1310(92.6 \%)$ \\
\hline \multirow{2}{*}{ Obesity } & Obese & Non Obese \\
\hline & $619(43.7 \%)$ & $796(56.3 \%)$ \\
\hline \multirow[t]{2}{*}{ Hypertension } & Hypertensive & No hypertension \\
\hline & $635(45 \%)$ & $780(55 \%)$ \\
\hline \multirow[t]{2}{*}{ Dyslipidemia Status } & With dyslipidemia & Without Dyslipidemia \\
\hline & $806(57 \%)$ & $609(43 \%)$ \\
\hline \multirow[t]{2}{*}{ PTCA Status } & Post PTCA & Without PTCA \\
\hline & $105(7.4 \%)$ & $1310(92.6 \%)$ \\
\hline \multirow{2}{*}{$\begin{array}{l}\text { CABG (coronary artery } \\
\text { bypass graft) Status }\end{array}$} & Post CABG & Without CABG \\
\hline & $35(2.5 \%)$ & $1380(97.8 \%)$ \\
\hline \multirow{2}{*}{$\begin{array}{l}\text { Ischemic Heart Disease } \\
\text { Status (including post } \\
\text { PTCA and CABG) }\end{array}$} & With IHD & Without IHD \\
\hline & $305(21.6 \%)$ & $1110(78.4 \%)$ \\
\hline \multirow[t]{2}{*}{ Microalbumin in Urine } & With Micro-albuminuria & $\begin{array}{l}\text { Without } \\
\text { albuminuria }\end{array}$ \\
\hline & $295(20.8 \%)$ & $1120(79.2 \%)$ \\
\hline \multirow{2}{*}{$\begin{array}{l}\text { Overall Nephropathy } \\
\text { Status }\end{array}$} & With Nephropathy & Without Nephropathy \\
\hline & $435(30.7 \%)$ & $1037(73.3 \%)$ \\
\hline
\end{tabular}

Table 1: Demographic data for diabetic patients

Descriptive statistics with mean and standard deviation $( \pm \mathrm{SD})$ for the other interested variables, BMI, HbAlc, serum creatinine, serum lipids, urinary micro-albumin, systolic and diastolic blood pressure, are shown in Table 2.

Interested variables (diabetes duration, $\mathrm{HbAlc}$, serum creatinine, HDL-C, and micr-oalbumin in urine) were statistically compared among the two groups of the patients, IHD and without IHD status, and results are summarized with Mean, SD with 95\% CI in Table 3. It should be noted that total cholesterol, triglycerides and LDL-C were not tested in IHD profile as all patients with IHD were on statin therapy which significantly lowers these lipids.

\begin{tabular}{|l|l|}
\hline \multicolumn{2}{|c|}{ Descriptive Statistics For Variables of Interest } \\
\hline \multicolumn{1}{|c|}{ Variables } & \multicolumn{1}{c|}{ Mean \pm SD } \\
\hline Age (years) & $56.45 \pm 14.77$ \\
\hline Diabetes Duration (years) & $14.7 \pm 9.06$ \\
\hline BMI (kg/m²) & $29.59 \pm 5.91$ \\
\hline HbA1c \% ( g/dL) & $9.66 \pm 2.18$ \\
\hline Serum Creatinine (mg/dl) & $1.021 \pm 0.73$ \\
\hline Triglyceride (mg/dl) & $156.46 \pm 96.26$ \\
\hline Total Cholesterol (mg/dl) & $190.84 \pm 48.757$ \\
\hline HDL-Cholesterol (mg/dl) & $41.63 \pm 13.54$ \\
\hline LDL-Cholesterol (mg/dl) & $117.78 \pm 41.49$ \\
\hline $\begin{array}{l}\text { Microalbumin in Urine (mg/L) / Urine Albumin } \\
\text { Excretion (UAE) }\end{array}$ & $79.67 \pm 109.94$ \\
\hline Systolic BP (mmHg) & $126.81 \pm 17.14$ \\
\hline Diastolic BP (mmHg) & $78.66 \pm 9.2$ \\
\hline
\end{tabular}

Table 2: Variables with Mean \pm SD

\begin{tabular}{|c|c|c|c|}
\hline \multicolumn{4}{|c|}{ Ischemic Heart Disease Profile Analysis } \\
\hline \multirow{3}{*}{$\begin{array}{l}\text { Variables } \\
\text { Indicators }\end{array}$} & \multicolumn{3}{|c|}{ Patients Variable Values With or Without IHD } \\
\hline & \multicolumn{2}{|c|}{ Mean \pm SD $(95 \% \mathrm{Cl})$} & \multirow[b]{2}{*}{ P-value } \\
\hline & With IHD & Without IHD & \\
\hline \multirow[t]{2}{*}{ Diabetes Duration } & $17.82 \pm 8.21$ & $14.30 \pm 9.09$ & \\
\hline & $\begin{array}{l}(95 \% \mathrm{Cl} 16.22 \text { to } \\
19.43\end{array}$ & $\begin{array}{l}(95 \% \mathrm{Cl} 13.68 \\
\text { to } 14.93)\end{array}$ & $<0.0001$ \\
\hline \multirow[t]{2}{*}{$\mathrm{HbA} 1 \mathrm{c} \%(\mathrm{~g} / \mathrm{dL})$} & $9.84 \pm 2.08$ & $9.641 \pm 2.1936$ & \\
\hline & $\begin{array}{l}(95 \% \text { Cl } 9.43 \text { to } \\
10.2)\end{array}$ & $\begin{array}{l}(95 \% \text { Cl } 9.4 \text { to } \\
9.791)\end{array}$ & 0.043 \\
\hline \multirow[t]{2}{*}{ Serum Creatinine $(\mathrm{mg} / \mathrm{dl})$} & $1.149 \pm 0.66$ & $1.004 \pm 0.73$ & \\
\hline & $\begin{array}{l}(95 \% \text { Cl } 1.02 \text { to } \\
1.28)\end{array}$ & $\begin{array}{l}(95 \% \mathrm{Cl} 0.95 \\
\text { to } 1.05)\end{array}$ & 0.007 \\
\hline \multirow[t]{2}{*}{$\mathrm{HDL}-\mathrm{C}(\mathrm{mg} / \mathrm{dl})$} & $38.7 \pm 13.39$ & $42 \pm 13.52$ & \\
\hline & $\begin{array}{l}(95 \% \mathrm{Cl} 36.02 \text { to } \\
41.39)\end{array}$ & $\begin{array}{l}(95 \% \mathrm{Cl} 41.05 \\
\text { to } 42.95)\end{array}$ & $<0.0001$ \\
\hline \multirow[t]{2}{*}{ Systolic BP (mmHg) } & $129.27 \pm 16.82$ & $126.50 \pm 17.16$ & \\
\hline & $\begin{array}{l}(95 \% \mathrm{Cl} 125.98 \\
\text { to } 132.56)\end{array}$ & $\begin{array}{|ll|}(95 \% & \mathrm{Cl} \\
125.33 & \text { to } \\
127.67) & \end{array}$ & 0.11 \\
\hline \multirow[t]{2}{*}{$\begin{array}{l}\text { Microalbumin in Urine } \\
\text { (mg/L) }\end{array}$} & $98.9708 \pm 114.37$ & $\begin{array}{l}76.2411 \\
108.93\end{array}$ & \\
\hline & \begin{tabular}{|lll}
$(95 \%$ & $\mathrm{Cl}$ & 70.62 \\
to127.31) &
\end{tabular} & $\begin{array}{l}(95 \% \mathrm{Cl} 65.02 \\
\text { to } 87.45)\end{array}$ & $<0.0001$ \\
\hline
\end{tabular}

Table 3: Grouped variables with and without IHD 
Citation: Aziz KMA (2014) Association of Microalbuminuria with Ischemic Heart Disease, Dyslipidemia and Obesity among Diabetic Patients: Experience from 5 Year Follow up Study of 1415 Patients. Bioenergetics 3: 118. doi: 10.4172/2167-7662.1000118

Page 4 of 10

It was found that those with IHD had mean duration of diabetes 17.82 years as compared to those without IHD, with the mean 14.3 years $(\mathrm{p}<0.0001)$. HbA1c, Serum creatinine, and urine micro-albumin levels were also found to be higher with the IHD as compared to those without IHD, while HDL-C levels were on lower side with IHD.

The selected interested variables (duration of diabetes, HbAlc, serum creatinine, systolc BP, BMI and all lipids) were compared among the two groups of patients, with nephropathy and without nephropathy and the results with the mean \pm SD and 95\% CI are presented in Table 4. Duration of diabetes was found to be more in the group with nephropathy. Subjects with nephropathy demonstrated a higher BMI, systolic BP, $\mathrm{HbAlc}$, serum creatinine, and all serum lipid values except for HDL-C which was observed to be non-significantly lower in the group with nephropathy.

\begin{tabular}{|c|c|c|c|}
\hline \multicolumn{4}{|c|}{ Nephropathy Profile Analysis } \\
\hline \multirow[t]{2}{*}{$\begin{array}{l}\text { Variables and } \\
\text { Indicators }\end{array}$} & \multicolumn{3}{|c|}{$\begin{array}{l}\text { Patients Variable Values With or Without } \\
\text { Nephropathy Mean } \pm \text { SD }(95 \% \mathrm{Cl})\end{array}$} \\
\hline & $\begin{array}{l}\text { With } \\
\text { Nephropathy }\end{array}$ & $\begin{array}{l}\text { Without } \\
\text { Nephropathy }\end{array}$ & P-value \\
\hline Diabetes Duration & $\begin{array}{l}17.4833 \pm 9.24 \\
(95 \% \mathrm{Cl} 16.22 \text { to } \\
18.53)\end{array}$ & 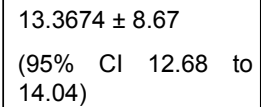 & $<0.0001$ \\
\hline $\mathrm{HbA} 1 \mathrm{c} \%(\mathrm{~g} / \mathrm{dL})$ & $\begin{array}{l}9.978 \pm 2.15 \\
(95 \% \text { Cl } 9.73 \text { to } \\
10.22)\end{array}$ & $\begin{array}{l}9.513 \pm 2.17 \\
(95 \% \mathrm{Cl} 9.34 \text { to } 9.68)\end{array}$ & $<0.0001$ \\
\hline $\begin{array}{l}\text { Serum } \\
(\mathrm{mg} / \mathrm{dl})\end{array} \quad$ Creatinine & $\begin{array}{l}1.287 \pm 1.06 \\
(95 \% \mathrm{Cl} 1.166 \text { to } \\
1.4)\end{array}$ & $\begin{array}{l}0.891 \pm 0.43 \\
(95 \% \mathrm{Cl} 0.85 \text { to } 0.92)\end{array}$ & $<0.0001$ \\
\hline HDL-C (mg/dl) & $\begin{array}{l}41.03 \pm 11.76 \\
(95 \% \mathrm{Cl} 39.67 \text { to } \\
42.39)\end{array}$ & \begin{tabular}{|l}
$41.93 \pm 14.33$ \\
$(95 \%$ Cl 40.77 to \\
$43.08)$
\end{tabular} & 0.142 \\
\hline $\begin{array}{l}\text { Total-Cholesterol } \\
(\mathrm{mg} / \mathrm{dl})\end{array}$ & $\begin{array}{l}198.17 \pm 51.80 \\
(95 \% \mathrm{Cl} 192.23 \text { to } \\
204.11)\end{array}$ & $\begin{array}{l}187.25 \pm 46.82 \\
(95 \% \mathrm{Cl} 183.51 \text { to } \\
191.00)\end{array}$ & 0.032 \\
\hline LDL-C (mg/dl) & $\begin{array}{l}123.80 \pm 44.305 \\
(95 \% \mathrm{Cl} 118.64 \text { to } \\
128.95)\end{array}$ & $\begin{array}{l}114.86 \pm 39.779 \\
(95 \% \text { Cl } 111.65 \text { to } \\
118.08)\end{array}$ & 0.014 \\
\hline Triglycerides (mg/dl) & $\begin{array}{l}170.20 \pm 110.98 \\
(95 \% \mathrm{Cl} 157.49 \text { to } \\
182.92)\end{array}$ & 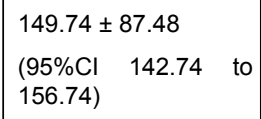 & 0.005 \\
\hline Systolic BP (mmHg) & $\begin{array}{l}136.76 \pm 18.43 \\
(95 \% \mathrm{Cl} 134.67 \text { to } \\
138.86)\end{array}$ & $\begin{array}{l}122.04 \pm 14.20 \\
(95 \% \text { Cl } 120.92 \text { to } \\
123.15)\end{array}$ & $<0.0001$ \\
\hline $\operatorname{BMI}\left(\mathrm{kg} / \mathrm{m}^{2}\right)$ & $\begin{array}{l}29.829 \pm 5.76 \\
(95 \% \text { Cl } 29.17 \text { to } \\
30.48)\end{array}$ & $\begin{array}{l}29.486 \pm 5.98 \\
(95 \% \text { Cl } 29.016 \text { to } \\
29.95)\end{array}$ & 0.831 \\
\hline
\end{tabular}

Table 4: Grouped variables with and without nephropathy

Variables (BMI, HbA1c, serum creatinine, micro-albuminuria, and systolic BP) were compared among the two groups, with and without dyslipidemia. Statistical results with mean, SD and 95\% CI are presented in the Table 5. It was observed that dyslipidemia group exhibited higher BMI, systolic BP, HbAlc, serum creatinine, and micro-albumin in urine.

\begin{tabular}{|c|c|c|c|}
\hline \multicolumn{4}{|c|}{ Dyslipidemia Profile Analysis } \\
\hline $\begin{array}{l}\text { Variables and } \\
\text { Indicators }\end{array}$ & $\begin{array}{l}\text { Patients Variable Va } \\
\text { Mean } \pm \text { SD }(95 \% \mathrm{Cl})\end{array}$ & lues With or Without Dy & slipidemia \\
\hline & With Dyslipidemia & Without Dyslipidemia & P-Value \\
\hline BMI $\left(\mathrm{kg} / \mathrm{m}^{2}\right)$ & \begin{tabular}{|l}
$29.841 \pm 5.84$ \\
$(95 \% \mathrm{Cl} \quad 29.39$ to \\
$30.28)$
\end{tabular} & $\begin{array}{l}29.004 \pm 6.05 \\
(95 \% \mathrm{Cl} 28.27 \text { to } 29.73)\end{array}$ & 0.037 \\
\hline $\mathrm{HbA} 1 \mathrm{c} \%(\mathrm{~g} / \mathrm{dL})$ & $\begin{array}{l}9.777 \pm 2.18 \\
(95 \% \text { Cl } 9.60 \text { to } 9.94)\end{array}$ & $\begin{array}{l}9.388 \pm 2.15 \\
(95 \% \mathrm{Cl} 9.12 \text { to } 9.64)\end{array}$ & 0.51 \\
\hline $\begin{array}{l}\text { serum creatinine } \\
(\mathrm{mg} / \mathrm{dl})\end{array}$ & $\begin{array}{l}1.027 \pm 0.77 \\
(95 \% \mathrm{Cl} 0.96 \text { to } 1.08)\end{array}$ & $\begin{array}{l}1.004 \pm 0.62 \\
(95 \% \mathrm{Cl} 0.92 \text { to } 1.07)\end{array}$ & 0.043 \\
\hline $\begin{array}{l}\text { Microalbumin } \\
\text { in urine }(\mathrm{mg} / \mathrm{L})\end{array}$ & $\begin{array}{l}83.17 \pm 114.75 \\
(95 \% \text { Cl } 70.24 \text { to } \\
96.10)\end{array}$ & $\begin{array}{l}71.14 \pm 97.09 \\
(95 \% \text { Cl } 53.95 \text { to } 88.33)\end{array}$ & 0.02 \\
\hline $\begin{array}{l}\text { Systolic } \\
(\mathrm{mmHg})\end{array}$ & \begin{tabular}{|lll} 
& $127.28 \pm 16.84$ & \\
$(95 \% \mathrm{Cl} \quad 126$ & to \\
$128.57)$ &
\end{tabular} & $\begin{array}{l}125.67 \pm 17.82 \\
(95 \% \text { Cl } 123.53 \text { to } \\
127.80)\end{array}$ & 0.015 \\
\hline
\end{tabular}

Table 5: Grouped variables with and without dyslipidemia

\begin{tabular}{|c|c|c|c|}
\hline \multicolumn{4}{|c|}{ Obesity Profile Analysis } \\
\hline \multirow[t]{2}{*}{$\begin{array}{l}\text { Variables } \quad \text { and } \\
\text { Indicators }\end{array}$} & \multicolumn{3}{|c|}{$\begin{array}{l}\text { Patients Variable Values With or Without Obesity } \\
\text { Mean } \pm \text { SD }(95 \% \mathrm{Cl})\end{array}$} \\
\hline & $\begin{array}{l}\text { Patients without } \\
\text { Obesity }(\mathrm{BMI}<30 \\
\left.\mathrm{kg} / \mathrm{m}^{2}\right)\end{array}$ & $\begin{array}{l}\text { Patients with } \\
\text { Obesity (BMI } \geq 30 \\
\left.\mathrm{~kg} / \mathrm{m}^{2}\right)\end{array}$ & P-value \\
\hline $\begin{array}{l}\text { Triglycerides } \\
(\mathrm{mg} / \mathrm{dl})\end{array}$ & $\begin{array}{l}163.96 \pm 104.74 \\
(95 \% \mathrm{Cl} 147.96 \text { to } \\
179.96) \\
\mathrm{SEM} \pm 8.105\end{array}$ & \begin{tabular}{|l|}
$151.56 \pm 78.54$ \\
$(95 \% \mathrm{Cl} \quad 141.59$ to \\
$161.52)$ \\
$\mathrm{SEM} \pm 5.059$
\end{tabular} & 0.002 \\
\hline $\begin{array}{l}\text { Total-Cholesterol } \\
(\mathrm{mg} / \mathrm{dl})\end{array}$ & $\begin{array}{l}197.51 \pm 56.81 \\
(95 \% \mathrm{Cl} 188.83 \text { to } \\
206.19)\end{array}$ & $\begin{array}{l}187.84 \pm 46.85 \\
(95 \% \mathrm{Cl} 181.90 \text { to } \\
193.79)\end{array}$ & 0.04 \\
\hline $\begin{array}{l}\text { HDL Cholesterol } \\
(\mathrm{mg} / \mathrm{dl})\end{array}$ & $\begin{array}{l}41.68 \pm 13.29 \\
(95 \% \text { Cl } 39.65 \text { to } \\
43.71\end{array}$ & $\begin{array}{l}43.17 \pm 14.09 \\
(95 \% \mathrm{Cl} 41.38 \text { to } \\
44.95)\end{array}$ & 0.03 \\
\hline $\begin{array}{l}\mathrm{LDL} \\
(\mathrm{mg} / \mathrm{dl})\end{array}$ & $\begin{array}{l}122.41 \pm 45.65 \\
(95 \% \text { Cl } 115.44 \text { to } \\
129.39)\end{array}$ & $\begin{array}{l}114.58 \pm 41.26 \\
(95 \% \mathrm{Cl} 109.34 \text { to } \\
119.81)\end{array}$ & 0.037 \\
\hline $\begin{array}{l}\text { Systolic BP } \\
(\mathrm{mmHg})\end{array}$ & $\begin{array}{l}131.13 \pm 17.09 \\
(95 \% \text { Cl } 128.52 \text { to } \\
133.74)\end{array}$ & $\begin{array}{l}124.90 \pm 16.59 \\
(95 \% \text { Cl } 122.79 \text { to } \\
127)\end{array}$ & $<0.0001$ \\
\hline $\begin{array}{l}\text { Urinary Albumin } \\
\text { Excretion }(\mathrm{mg} / \mathrm{L})\end{array}$ & $\begin{array}{l}89.6569 \pm 112.73 \\
(95 \% \mathrm{Cl} 72.43 \text { to } \\
106.88)\end{array}$ & $\begin{array}{l}71.3959 \pm 108.21 \\
(95 \% \text { Cl } 57.66 \text { to } \\
85.12)\end{array}$ & 0.02 \\
\hline
\end{tabular}

Table 6: Grouped variables with and without Obesity 
Citation: Aziz KMA (2014) Association of Microalbuminuria with Ischemic Heart Disease, Dyslipidemia and Obesity among Diabetic Patients: Experience from 5 Year Follow up Study of 1415 Patients. Bioenergetics 3: 118. doi: 10.4172/2167-7662.1000118

Page 5 of 10

Regarding the obesity profile analysis, variables (triglycerides, total cholesterol, HDL-C, LDL-C, systolic BP, and micro-albuminuria) were compared with and without obesity status. All significant statistical results are presented in Table 6. Systolic BP, micro-albuminuria levels (UAE or urinary albumin excretion) and lipids were observed to be higher in obese diabetic population except for HDL-C which was observed to be on lower levels with obesity.

The categorical data (status or profiles) of IHD, nephropathy, and obesity with HTN and micro-albuminuria were tested for significant statistical associations with Pearson's chi-square test and are presented in Table 7 with their explanations. All results were significant with higher odds ratios except for the dyslipidemia with IHD.

Data for BMI, HDL, micro-albuminuria, systolic and diastolic BP were tested for the significant bivariate correlations and are presented in Table 8 .

\section{Discussion}

Current study is confirmatory for the past studies. However, no research study could be found among diabetic patients who have enrolled patients to monitor multiple risk factors and their significant association at cross sectional level. Hence, our study is of first kind to find such associations simultaneously.

According to the observed results of the current study, it was found that most of the diabetic patients under the study were obese (43.7\%). Prevalence of dyslipidemia was also found to be much higher (70.8\%). Similarly nephropathy status was again significantly high $(30.7 \%)$. These observations are alarming and matching with the world wide data. High body mass index (BMI) and sedentary lifestyle is a risk factor for the IHD or CAD and as well as development of microalbuminuria [54]. Furthermore, Glycemic control should be near the defined targets to prevent diabetes complications. The benefits of intensive diabetes management to prevent cardiovascular complications has been demonstrated and documented in research literature [50,55,56]. For monitoring diabetes, $\mathrm{HbA1c}$ is now a standard methodology in diabetology clinics, which measures patient's glycemic control for the past 2-3 months [57].

\begin{tabular}{|c|c|c|c|c|c|}
\hline \multicolumn{6}{|c|}{ Significant Statistical Associations Between Categorical Variables : } \\
\hline \multicolumn{6}{|c|}{ IHD, Nephropathy, Dyslipidemia and Obesity Status } \\
\hline \multirow[t]{3}{*}{$\begin{array}{l}\text { Variables Tested } \\
\text { Together for } \\
\text { Significant } \\
\text { Associations }\end{array}$} & $\begin{array}{c}\text { Pearso } \\
\text { n Chi } \\
\text { Square }\end{array}$ & $\begin{array}{c}\text { Likelihoo } \\
\text { d Ratio }\end{array}$ & $\begin{array}{l}\text { Fisher' } \\
\text { s Exact } \\
\text { Test }\end{array}$ & $\begin{array}{c}\text { Linear-by- } \\
\text { Linear } \\
\text { Associatio } \\
n\end{array}$ & $\begin{array}{l}\text { Logistic } \\
\text { Regressio } \\
\mathrm{n} \text { and }\end{array}$ \\
\hline & p-value & p-value & p-value & p-value & $\begin{array}{l}\text { Odds } \\
\text { Ratio }\end{array}$ \\
\hline & & & & & $(95 \% \mathrm{Cl})$ \\
\hline $\begin{array}{l}\text { IHD with } \\
\text { Nephropathy }\end{array}$ & $<0.0001$ & $<0.0001$ & $<0.0001$ & $<0.0001$ & $\begin{array}{l}2.16(1.43 \\
\text { to } 3.271)\end{array}$ \\
\hline HTN with IHD & $<0.0001$ & $<0.0001$ & $<0.0001$ & $<0.0001$ & $\begin{array}{l}6.53(3.9 \text { to } \\
10.96)\end{array}$ \\
\hline $\begin{array}{l}\text { Microalbuminuria } \\
\text { with IHD }\end{array}$ & $<0.0001$ & $<0.0001$ & $<0.0001$ & $<0.0001$ & $\begin{array}{l}3.53(2.27 \\
\text { to } 5.5)\end{array}$ \\
\hline $\begin{array}{l}\text { HTN with } \\
\text { Nephropathy }\end{array}$ & $<0.0001$ & $<0.0001$ & $<0.0001$ & $<0.0001$ & $\begin{array}{l}3.97(2.96 \\
\text { to } 5.31)\end{array}$ \\
\hline Obesity with HTN & $<0.0001$ & $<0.0001$ & $<0.0001$ & $<0.0001$ & $\begin{array}{l}1.63(1.25 \\
\text { to } 2.12)\end{array}$ \\
\hline $\begin{array}{l}\text { Dyslipidemia with } \\
\text { IHD }\end{array}$ & $<0.0001$ & $<0.0001$ & $<0.0001$ & $<0.0001$ & $\begin{array}{l}0.37 \quad(0.24 \\
\text { to } 0.56)\end{array}$ \\
\hline
\end{tabular}

Table 7: Significant Associations among variables IHD, nephropathy, dyslipidemia, microalbuminuria, obesity and hypertension with their explanations

\begin{tabular}{|c|c|c|c|c|c|c|c|c|}
\hline \multicolumn{9}{|c|}{ Significant Statistical Associations of Continuous Data } \\
\hline \multirow[t]{2}{*}{ Variables } & \multirow{2}{*}{$\begin{array}{l}\text { Pearson } \\
\text { Correlation }(r)\end{array}$} & \multirow{2}{*}{$\begin{array}{l}p \text {-value } \\
\text { for } \\
\text { correlation }\end{array}$} & \multicolumn{6}{|c|}{ Regression Analysis / Model } \\
\hline & & & $\mathbf{R}^{2}$ & $\mathbf{F}$ & $\begin{array}{l}\text { ANOVA } \\
\text { model } \\
\text { P-value }\end{array}$ & $\mathbf{t}$ & P-value & $\begin{array}{l}\text { Regression model or } \\
\text { equation }\end{array}$ \\
\hline BMI and HDL-C & $r=-0.074$ & $<0.05$ & .005 & 4.8 & 0.029 & $\begin{array}{ll}20 & \prime \\
-2.1\end{array}$ & $<0.0001$ & $\mathrm{HDL}=46.6+(-0.169 \times \mathrm{BMI})$ \\
\hline $\begin{array}{l}\text { systolic } \mathrm{BP} \text { and } \\
\text { Microalbu-minuria }\end{array}$ & $r=0.366$ & $<0.0001$ & 0.134 & 66.2 & $<0.0001$ & $\begin{array}{l}-5.9 / \\
8.1\end{array}$ & $<0.0001$ & $\begin{array}{l}\text { Microalbuminuria }=-218.6+ \\
(2.34 \times \text { systolic BP })\end{array}$ \\
\hline $\begin{array}{l}\text { diastolic BP and } \\
\text { Microalbu- } \\
\text { minuria }\end{array}$ & $r=0.274$ & $<0.0001$ & 0.075 & 34.6 & $<0.0001$ & $\begin{array}{l}-3.9 / \\
5.8\end{array}$ & $<0.0001$ & $\begin{array}{l}\text { Microalbuminuria }=-166+ \\
(3.1 \times \text { systolic BP })\end{array}$ \\
\hline
\end{tabular}

Table 8: Significant Pearson's correlation and associations among variables

In the current study, when IHD profile was analyzed, it was found that HbAlc levels were higher for the patients with a history of IHD as compared to those without history of IHD $(\mathrm{P}<0.0001)$. Serum creatinine was higher in IHD group compared to those without $(\mathrm{P}=0.007)$ indicating a link between IHD or CAD and renal impairment or diabetic kidney disease (DKD) [58-60]. This was further supported by the evidence that urine microalbumin levels were higher among IHD group $(\mathrm{P}<0.0001)$. Additionally systolic BP was again non-significantly higher in IHD group $(\mathrm{p}=0.11)$. However, association between HTN and IHD was highly significant $\left(\chi^{2}\right.$ p-value $<$ 0.0001). Hence it can be concluded that hypertension and hyperglycemia precedes the development of incipient nephropathy $[61,62]$. As evident by results (Table 7), association between the two variables, IHD and development of microalbuminuria, was highly 
significant $\left(\chi^{2} \mathrm{p}\right.$-value $\left.<0.0001\right)$, concluding that microalbuminuria is a predictor of future developments of IHD/CAD. HDL cholesterol levels were observed to be reduced in IHD group $(\mathrm{P}<0.0001)$. HDL-C is good cholesterol and elevated HDL-C levels are protective against CAD/IHD development $[63,64]$. HDL-C levels can effectively be raised by regular exercise/activity or daily regular walk [65]. Furthermore, in the current study association between dyslipidemia and development of IHD was again significant $\left(\chi^{2} p\right.$-value $\left.<0.0001\right)$, indicating the role of lipid management in diabetes to prevent cardiac disease [63,64]. However, the odds ratio was 0.37 ( $95 \%$ CI 0.24 to 0.56 ). This was due to the fact that most of the subjects with IHD were on statins therapy.

Regarding nephropathy profile analysis, most of the patients (30.7\%) that developed nephropathy, had duration of diabetes more than 17 years, nearly matching with IHD profile. This might indicate development of the two diseases soon after the other or simultaneously. For the glycemic status, HbAlc levels were higher in nephropathy group $(\mathrm{P}<0.0001)$. In other words, reducing blood sugars and $\mathrm{HbAlc}$ to the targets will prevent nephropathy and better prognosis in nephropathy and ESRD as well [66-69]. Serum creatinine, lipids was observed to be higher in nephropathy group $(\mathrm{P}<0.0001)$. Creatinine is an indicator of renal function and should be monitored periodically in diabetic patients. It has been documented that dyslipidemia contributes to the progression of DKD and nephropathy. Furthermore, IHD and nephropathy demonstrated significant association $\left(\chi^{2}\right.$ p-value $\left.<0.0001\right)$. These all observations indicate the importance of dyslipidemia management in diabetic patients with albuminuria/ DKD and IHD [70]. Systolic BP was higher among nephropathy group $(\mathrm{p}<0.0001)$. Association between HTN and development of nephropathy was statistically significant $\left(\chi \chi^{2} \mathrm{p}\right.$-value $<$ 0.0001 ) and it was observed that bivariate correlation and regression analysis for microalbuminuria with systolic blood pressure and diastolic blood pressure was highly significant ( $p$-value $<0.0001$; $\mathrm{r}=0.366$ and $\mathrm{p}$-value $<0.0001 ; \mathrm{r}=0.274$ respectively). In type- 1 and type-2 diabetic patients, natural history of DKD usually demonstrates initially elevated blood pressure or HTN, albuminuria and then finally decreased GFR [71]. It has been demonstrated by randomized controlled trials that HTN is a risk factor for progression of nephropathy or DKD while antihypertensive therapy with ACE (angiotensin converting enzyme) inhibitors, calcium channel blocker, and ARBs (angiotensin receptor blockers) reduces this risk [16,72-80]. Also it is recommended that diabetic hypertensive patients should be treated with ACE inhibitors or ARBs, usually in combination with a diuretic. Target blood pressure for diabetics and those with DKD/CKD stages 1-4 should be $<130 / 80 \mathrm{mmHg}$ [16]. Statistical results also have shown that in the current study BMI was non-significantly higher among nephropathy group $(29.829 \pm 5.76$ versus $29.486 \pm 5.9844$; pvalue 0.831 ). This was an incidental non-significant finding. Hence obesity may be associated with proteinuria and could be a risk factor for ESRD [81,82].

It was found that subject labeled with dyslipidemia showed a higher mean BMI. It is well known that subjects with a more abdominal type of fat distribution are at increased of developing type- 2 diabetes $[83,84]$. Thus treatment of obesity and dyslipidemia is essential. Higher HbAlc levels with the dyslipidemia group was another finding of this study, although non-significant $(p=0.5)$. In fact, it has been found that defects in insulin action or diabetes state can lead to changes in plasma lipoproteins and lipid abnormalities exclusive of hyperglycemia $[85,86]$. As indicated by results, serum creatinine was significantly higher among dyslipimia group, indicating association of dyslipidemia with renal impairment. It has been stated in research literature that lipids contribute to the development and progression of nephropathy [87-90]. Furthermore, it was observed that mean microalbumin levels were higher among dyslipidemia group (83.17 \pm 114.75 versus $71.14 \pm 97 ; \mathrm{p}=0.02$ ). This explains effects of dyslipidemia among diabetic patients in the development of incipient nephropathy. Similarly, systolic BP values were higher in nephropathy group (127.28 \pm 16.84 versus $125.67 \pm 17.82 ; \mathrm{p}=0.015)$. All these pathologies, dyslipidemia, hyperglycemia, and HTN significantly trigger the development of microalbuminuria/DKD. Microalbuminuria, if not treated early, may further leads to nephropathy, DKD, and later on ESRD over the next few years both in type-1 and type-2 patients [91-97].

Regarding the results of obesity profile analysis, total cholesterol, triglyceride, and LDL-C levels were observed high in obesity group, while HDL-C levels were found to be on lower side (Table 6). One of the statistically significant finding observed in this diabetic population was bivariate correlation of BMI with HDL-C while both variable were negatively associated $(\mathrm{r}=-0.074$; $\mathrm{p}$-value $<0.05)$, a fact indicating an inverse relation, i.e., high BMI and low HDL, and vice versa. Existence of both obesity and dyslipidemia together is well known [98-101]. Similarly, weight reduction programs and strategies for obesity / visceral obesity have shown to reduce the cardiovascular risk and better outcomes [102-105]. In the current study, obesity status was also associated with high systolic BP comparative to its non-obese counterpart $(\mathrm{p}<0.0001)$. Association of weight and high BMI with blood pressure in young adults and children has been demonstrated in research trials [106-113]. Obesity is also associated with cardiovascular risk as well $[114,115]$. Our data has indicated that obesity is associated with development of high systolic BP and HTN. Additionally, mean urinary albumin excretion rate was significantly higher among obese subjects $(89.65 \pm 112.73$ versus $71.39 \pm 108.21 ; \mathrm{p}=0.02)$, explaining the fact of association of incipient nephropathy with obesity $[116,117]$.

Limitations of the current study included non-randomization, and there was no control group. Further Randomized controlled, multicenter studies are required to confirm simultaneous positive findings and observations of the current study. Further studies are required to investigate these relationships in depth.

\section{Conclusion and Recommendations}

Diabetes mellitus is cardiovascular risk equivalent. Microalbuminuria predicts the future risk for the development of ischemic heart events (IHD/CAD) and diabetic kidney disease and ESRD.

Therefore it is recommended that all diabetic patients should be screened at primary care level soon after the diagnosis or at first presentation for co-morbid conditions and risk factors. Diabetes education is an integral part of diabetes management and all diabetic patients should be educated for diabetes management and prevention of complications $[118,119]$. All diabetic patients should be referred to tertiary care diabetes center for follow up, monitoring, and adjustment of diabetes related therapy, to prevent diabetes complication and better prognosis. To manage diabetes and its associated disorders, it is advisable to follow best available guidelines [120,121].

\section{References}

1. King H, Aubert RA, Herman WH (1998) Global burden of diabetes, 1995-2025: Prevalence, numerical estimates, and projections. Diabetes Care 21: 1414-1431. 
2. Mathers CD, Loncar D (2006) Projections of global mortality and burden of disease from 2002 to 2030. PLoS Med 3: e442.

3. Rosamond W, Flegal K, Friday G, Furie K, Go A, et al. (2007) Heart disease and stroke statistics--2007 update: a report from the American Heart Association Statistics Committee and Stroke Statistics Subcommittee. Circulation 115: e69-171.

4. American Diabetes Association (2008) Economic costs of diabetes in the U.S. In 2007. Diabetes Care 31: 596-615.

5. Diabetes Statistics (1999) National Diabetes Information Clearinghouse: National Institute of Diabetes and Digestive and Kidney Diseases. NIH publication, Bethesda, USA: 99-3926.

6. US Department of Health and Human Services (1996) Physical Activity and Health: A Report of the Surgeon General. National Center for Chronic Disease Prevention and Health Promotion, Atlanta, USA.

7. Grundy SM, Benjamin IJ, Burke GL, Chait A, Eckel RH, et al. (1999) Diabetes and cardiovascular disease: a statement for healthcare professionals from the American Heart Association. Circulation 100: 1134-1146.

8. Natali A, Vichi S, Landi P, Severi S, L'Abbate A, et al. (2000) Coronary atherosclerosis in Type II diabetes: angiographic findings and clinical outcome. Diabetologia 43: 632-641.

9. Moreno PR, Murcia AM, Palacios IF, Leon MN, Bernardi VH, et al. (2000) Coronary composition and macrophage infiltration in atherectomy specimens from patients with diabetes mellitus. Circulation 102: 2180-2184.

10. Henry P, Makowski S, Richard P, Beverelli F, Casanova S, et al. (1997) Increased incidence of moderate stenosis among patients with diabetes: substrate for myocardial infarction? Am Heart J 134: 1037-1043.

11. BARI Investigators (2000) Seven-year outcome in the Bypass Angioplasty Revascularization Investigation (BARI) by treatment and diabetic status. J Am Coll Cardiol 35: 1122-1129.

12. Ritz E, Rychlík I, Locatelli F, Halimi S (1999) End-stage renal failure in type 2 diabetes: A medical catastrophe of worldwide dimensions. Am J Kidney Dis 34: 795-808

13. Gross JL, de Azevedo MJ, Silveiro SP, Canani LH, Caramori ML, et al. (2005) Diabetic nephropathy: diagnosis, prevention, and treatment. Diabetes Care 28: 164-176.

14. Mogensen CE, Chachati A, Christensen CK, Close CF, Deckert T, et al. (1985) Microalbuminuria: an early marker of renal involvement in diabetes. Uremia Invest 9: 85-95.

15. Mogensen CE (2000) Definition of diabetic renal disease in insulin dependent diabetes mellitus based on renal function tests: The Kidney and Hypertension in Diabetes Mellitus. Kluwer Academic Publishers, Boston, USA: 1-14.

16. KDOQI (2007) KDOQI Clinical Practice Guidelines and Clinical Practice Recommendations for Diabetes and Chronic Kidney Disease. Am J Kidney Dis 49: S12-154

17. Dinneen SF, Gerstein HC (1997) The association of microalbuminuria and mortality in non-insulin-dependent diabetes mellitus. A systematic overview of the literature. Arch Intern Med 157: 1413-1418.

18. Vaur L, Gueret P, Lievre M, Chabaud S, Passa P; DIABHYCAR Study Group (type 2 DIABetes, et al. (2003) Development of congestive heart failure in type 2 diabetic patients with microalbuminuria or proteinuria: observations from the DIABHYCAR (type 2 DIABetes, Hypertension, CArdiovascular Events and Ramipril) study. Diabetes Care 26: 855-860.

19. Adler AI, Stevens RJ, Manley SE, Bilous RW, Cull CA, et al. (2003) Development and progression of nephropathy in type 2 diabetes: the United Kingdom Prospective Diabetes Study (UKPDS 64). Kidney Int 63: 225-232.

20. Miettinen H, Haffner SM, Lehto S, Ronnemaa T, Pyorala K, et al. (1996) Proteinuria predicts stroke and other atherosclerotic vascular disease events in nondiabetic and non-insulin-dependent diabetic subjects. Stroke 27: 2033- 2039.

21. Valmadrid CT1, Klein R, Moss SE, Klein BE (2000) The risk of cardiovascular disease mortality associated with microalbuminuria and gross proteinuria in persons with older-onset diabetes mellitus. Arch Intern Med 160: 1093-1100.

22. Gall MA, Hougaard P, Borch-Johnsen K, Parving HH (1997) Risk factors for development of incipient and overt diabetic nephropathy in patients with non-insulin dependent diabetes mellitus: prospective, observational study. BMJ 314: 783-788.

23. Ravid M, Lang R, Rachmani R, Lishner M (1996) Long-term renoprotective effect of angiotensin-converting enzyme inhibition in non-insulin-dependent diabetes mellitus. A 7-year follow-up study. Arch Intern Med 156: 286-289.

24. Laakso M, Lehto S (1997) Epidemiology of macrovascular disease in diabetes. Diabetes Rev 5: 294-315.

25. Wingard DL, Barrett-Connor E (1995) Heart disease and diabetes: In Diabetes in America. (2ndedn). Harris MI, ed. Bethesda, Md., National Institutes of Health 95-1468: 429-448.

26. Wilson PW, D'Agostino RB, Levy D, Belanger AM, Silbershatz H, et al. (1998) Prediction of coronary heart disease using risk factor categories. Circulation 97: 1837-1847.

27. Wilson PW (1998) Diabetes mellitus and coronary heart disease. Am J Kidney Dis 32: S89-100.

28. Wingard DL, Barrett-Connor EL, Scheidt-Nave C, McPhillips JB (1993) Prevalence of cardiovascular and renal complications in older adults with normal or impaired glucose tolerance or NIDDM. A population-based study. Diabetes Care 16: 1022-1025.

29. Rubler S, Dlugash J, Yuceoglu YZ, Kumral T, Branwood AW, et al. (1972) New type of cardiomyopathy associated with diabetic glomerulosclerosis. Am J Cardiol 30: 595-602.

30. Regan TJ, Lyons MM, Ahmed SS, Levinson GE, Oldewurtel HA, et al. (1977) Evidence for cardiomyopathy in familial diabetes mellitus. J Clin Invest 60: 884-899.

31. Gøtzsche O, Darwish A, Gøtzsche L, Hansen LP, Sørensen KE (1996) Incipient cardiomyopathy in young insulin-dependent diabetic patients: a seven-year prospective Doppler echocardiographic study. Diabet Med 13: 834-840.

32. Spector KS (1998) Diabetic cardiomyopathy. Clin Cardiol 21: 885-887.

33. World Health Organization (WHO) (1999) Report of a WHO Consultation: Definition, diagnosis and classification of diabetes mellitus and its complications, Geneva, Switzerland.

34. Rea S, James DE (1997) Moving GLUT4: the biogenesis and trafficking of GLUT4 storage vesicles. Diabetes 46: 1667-1677.

35. Shepherd PR, Withers DJ, Siddle K (1998) Phosphoinositide 3-kinase: the key switch mechanism in insulin signalling. Biochem J 333: 471-490.

36. Bogardus C, Lillioja S, Mott D, Reaven GR, Kashiwagi A, et al. (1984) Relationship between obesity and maximal insulin-stimulated glucose uptake in vivo and in vitro in Pima Indians. J Clin Invest 73: 800-805.

37. Perseghin G, Price TB, Petersen KF, Roden M, Cline GW, et al. (1996) Increased glucose transport-phosphorylation and muscle glycogen synthesis after exercise training in insulin-resistant subjects. N Engl J Med 335: 1357-1362.

38. Rowe JW, Minaker KL, Pallotta JA, Flier JS (1983) Characterization of the insulin resistance of aging. J Clin Invest 71: 1581-1587.

39. Austin MA, King MC, Vranizan KM, Krauss RM (1990) Atherogenic lipoprotein phenotype. A proposed genetic marker for coronary heart disease risk. Circulation 82: 495-506.

40. Austin MA, Breslow JL, Hennekens CH, Buring JE, Willett WC, et al. (1988) Low-density lipoprotein subclass patterns and risk of myocardial infarction. JAMA 260: 1917-1921.

41. Grundy SM (1997) Small LDL, atherogenic dyslipidemia, and the metabolic syndrome. Circulation 95: 1-4.

42. Austin MA, Edwards KL (1996) Small, dense low density lipoproteins, the insulin resistance syndrome and noninsulin-dependent diabetes. Curr Opin Lipidol 7: 167-171.

43. Mostaza JM, Vega GL, Snell P, Grundy SM (1998) Abnormal metabolism of free fatty acids in hypertriglyceridaemic men: apparent insulin resistance of adipose tissue. J Intern Med 243: 265-274. 
44. Edelson GW, Sowers JR (1993) Insulin resistance in hypertension: a focused review. Am J Med Sci 306: 345-347.

45. Sowers JR (1990) Insulin resistance and hypertension. Mol Cell Endocrinol 74: C87-89.

46. Ferrannini E, Buzzigoli G, Bonadonna R, Giorico MA, Oleggini M, et al. (1987) Insulin resistance in essential hypertension. N Engl J Med 317: 350-357.

47. Singer DE, Nathan DM, Anderson KM, Wilson PW, Evans JC (1992) Association of $\mathrm{HbAlc}$ with prevalent cardiovascular disease in the original cohort of the Framingham Heart Study. Diabetes 41: 202-208.

48. Uusitupa MI, Niskanen LK, Siitonen O, Voutilainen E, Pyörälä K (1993) Ten-year cardiovascular mortality in relation to risk factors and abnormalities in lipoprotein composition in type 2 (non-insulindependent) diabetic and non-diabetic subjects. Diabetologia 36: 1175-1184.

49. [No authors listed] (1998) Effect of intensive blood-glucose control with metformin on complications in overweight patients with type 2 diabetes (UKPDS 34). UK Prospective Diabetes Study (UKPDS) Group. Lancet 352: 854-865.

50. Malmberg K (1997) Prospective randomised study of intensive insulin treatment on long term survival after acute myocardial infarction in patients with diabetes mellitus. DIGAMI (Diabetes Mellitus, Insulin Glucose Infusion in Acute Myocardial Infarction) Study Group. BMJ 314: 1512-1515.

51. Meigs JB, D'Agostino RB Sr, Nathan DM, Rifai N, Wilson PW; Framingham Offspring Study (2002) Longitudinal association of glycemia and microalbuminuria: the Framingham Offspring Study. Diabetes Care 25: 977-983.

52. Nathan DM, Cleary PA, Backlund JY, Genuth SM, Lachin JM, et al. (2005) Intensive diabetes treatment and cardiovascular disease in patients with type 1 diabetes. N Engl J Med 353: 2643-2653.

53. NATCOM Hospital Information System (NATCOM HIS) (2013) National Computer System Co, Ltd.

54. Wentworth JM, Fourlanos S, Colman PG (2012) Body mass index correlates with ischemic heart disease and albuminuria in long-standing type 2 diabetes. Diabetes Res Clin Pract 97: 57-62.

55. van den Berghe G, Wouters P, Weekers F, Verwaest C, Bruyninckx F, et al. (2001) Intensive insulin therapy in critically ill patients. N Engl J Med 345: 1359-1367.

56. Melidonis A, Stefanidis A, Tournis S, Manoussakis S, Handanis S, et al. (2000) The role of strict metabolic control by insulin infusion on fibrinolytic profile during an acute coronary event in diabetic patients. Clin Cardiol 23: 160-164.

57. Little RR, Rohlfing CL, Wiedmeyer HM, Myers GL, Sacks DB, et al. (2001) The national glycohemoglobin standardization program: a fiveyear progress report. Clin Chem 47: 1985-1992.

58. Mattock MB, Barnes DJ, Viberti G, Keen H, Burt D, et al. (1998) Microalbuminuria and coronary heart disease in NIDDM: an incidence study. Diabetes 47: 1786-1792.

59. Ljungman S, Wikstrand J, Hartford M, Berglund G (1996) Urinary albumin excretion--a predictor of risk of cardiovascular disease. A prospective 10-year follow-up of middle-aged nondiabetic normal and hypertensive men. Am J Hypertens 9: 770-778.

60. Roest M, Banga JD, Janssen WM, Grobbee DE, Sixma JJ, et al. (2001) Excessive urinary albumin levels are associated with future cardiovascular mortality in postmenopausal women. Circulation 103: 3057-3061.

61. Ravid M, Brosh D, Ravid-Safran D, Levy Z, Rachmani R (1998) Main risk factors for nephropathy in type 2 diabetes mellitus are plasma cholesterol levels, mean blood pressure, and hyperglycemia. Arch Intern Med 158: 998-1004.

62. Viberti GC, Mogensen CE, Passa P, Bilous R, Mangli R (1994) Guidelines for the prevention of diabetic renal failure: The Kidney and Hypertension in Diabetes Mellitus. KJuwer Academic Publishers, Boston, USA: 515-527.
63. Adult Treatment Panel III (2001) Executive summary of the Third Report of the National Cholesterol Education Program (NCEP) expert panel on detection, evaluation, and treatment of high blood cholesterol in adults. JAMA 285: 2486-2496.

64. Genest J Jr (2002) Genetics and prevention: a new look at high-density lipoprotein cholesterol. Cardiol Rev 10: 61-71.

65. Spate-Douglas T, Keyser RE (1999) Exercise intensity: its effect on the high-density lipoprotein profile. Arch Phys Med Rehabil 80: 691-695.

66. Levin SR, Coburn JW, Abraira C, Henderson WG, Colwell JA, et al. (2000) Effect of intensive glycemic control on microalbuminuria in type 2 diabetes. Veterans Affairs Cooperative Study on Glycemic Control and Complications in Type 2 Diabetes Feasibility Trial Investigators. Diabetes Care 23: 1478-1485.

67. Brocco E, Velussi M, Cernigoi AM, Abaterusso C, Bruseghin M, et al (2001) Evidence of a threshold value of glycated hemoglobin to improve the course of renal function in type 2 diabetes with typical diabetic glomerulopathy. J Nephrol 14: 461-471.

68. Holman RR, Dornan TL, Mayon-White V, Howard-Williams J, OrdePeckar C, et al. (1983) Prevention of deterioration of renal and sensorynerve function by more intensive management of insulin-dependent diabetic patients. A two-year randomised prospective study. Lancet 1: 204-208.

69. Gerich JE, Meyer C, Woerle HJ, Stumvoll M (2001) Renal gluconeogenesis: its importance in human glucose homeostasis. Diabetes Care 24: 382-391.

70. Harris K, Thomas M, Short C, Moore R (2002) Assessment of the efficiency of treatment of dyslipidaemia in renal outpatients. J Nephrol 15: 263-269.

71. Dalla Vestra M, Saller A, Bortoloso E, Mauer M, Fioretto P (2000) Structural involvement in type 1 and type 2 diabetic nephropathy. Diabetes Metab 26 Suppl 4: 8-14.

72. Wachtell K, Palmieri V, Olsen MH, Bella JN, Aalto T, et al. (2002) Urine albumin/creatinine ratio and echocardiographic left ventricular structure and function in hypertensive patients with electrocardiographic left ventricular hypertrophy: the LIFE study. Losartan Intervention for Endpoint Reduction. Am Heart J 143: 319-326.

73. Agardh CD, Garcia-Puig J, Charbonnel B, Angelkort B, Barnett AH (1996) Greater reduction of urinary albumin excretion in hypertensive type II diabetic patients with incipient nephropathy by lisinopril than by nifedipine. J Hum Hypertens 10: 185-192.

74. Chan JC, Ko GT, Leung DH, Cheung RC, Cheung MY, et al. (2000) Long-term effects of angiotensin-converting enzyme inhibition and metabolic control in hypertensive type 2 diabetic patients. Kidney Int 57: 590-600.

75. Laffel LM, McGill JB, Gans DJ (1995) The beneficial effect of angiotensin-converting enzyme inhibition with captopril on diabetic nephropathy in normotensive IDDM patients with microalbuminuria. North American Microalbuminuria Study Group. Am J Med 99: 497-504.

76. Mathiesen ER, Hommel E, Giese J, Parving HH (1991) Efficacy of captopril in postponing nephropathy in normotensive insulin dependent diabetic patients with microalbuminuria. BMJ 303: 81-87.

77. Chobanian AV, Bakris GL, Black HR, Cushman WC, Green LA, et al. (2003) Seventh report of the Joint National Committee on Prevention, Detection, Evaluation, and Treatment of High Blood Pressure. Hypertension 42: 1206-1252.

78. Williams B, Lacy PS, Thom SM, Cruickshan K, Stanton A, et al. (2006) Differential Impact of Blood Pressure-Lowering Drugs on Central Aortic Pressure and Clinical Outcomes Principal Results of the Conduit Artery Function Evaluation (CAFE) Study. Circulation 113: 1213-1225.

79. Sever PS, Dahlof B, Poulter NR, Wedel H, Beevers DG, et al. (2001) Rationale, design, methods and baseline demography of participants of the Anglo-Scandinavian Cardiac Outcomes Trial. J Hypertens 19: 1139-1147.

80. Dahlöf B, Sever PS, Poulter NR, Wedel H, Beevers DG, et al. (2005) Prevention of cardiovascular events with an antihypertensive regimen of amlodipine adding perindopril as required versus atenolol adding 
bendroflumethiazide as required, in the Anglo-Scandinavian Cardiac Outcomes Trial-Blood Pressure Lowering Arm (ASCOT-BPLA): a multicentre randomised controlled trial. Lancet 366: 895-906.

81. Ramirez SP, McClellan W, Port FK, Hsu SI (2002) Risk factors for proteinuria in a large, multiracial, southeast Asian population. J Am Soc Nephrol 13: 1907-1917.

82. Tozawa M, Iseki K, Iseki C, Oshiro S, Ikemiya Y, et al. (2002) Influence of smoking and obesity on the development of proteinuria. Kidney Int 62: 956-962.

83. Vague J (1956) The degree of masculine differentiation of obesities: a factor determining predisposition to diabetes, atherosclerosis, gout and uric calculous disease. Am J ClinNutr 4: 20-34.

84. Krotkiewski M, Björntorp P, Sjöström L, Smith U (1983) Impact of obesity on metabolism in men and women. Importance of regional adipose tissue distribution. J Clin Invest 72: 1150-1162.

85. Goldberg IJ (2001) Clinical review 124: Diabetic dyslipidemia: causes and consequences. J Clin Endocrinol Metab 86: 965-971.

86. Savage DB, Petersen KF, Shulman GI (2007) Disordered lipid metabolism and the pathogenesis of insulin resistance. Physiol Rev 87: 507-520.

87. Thomas MC, Rosengård-Bärlund M, Mills V, Rönnback M, Thomas S, et al. (2006) Serum lipids and the progression of nephropathy in type 1 diabetes. Diabetes Care 29: 317-322.

88. Tolonen N, Forsblom C, Thorn L, Wadén J, Rosengård-Bärlund M, et al. (2008) Relationship between lipid profiles and kidney function in patients with type 1 diabetes. Diabetologia 51: 12-20.

89. Kamran MAA (2013) Association between Non-HDL and HDL Cholesterol with microalbuminuria in patients with Diabetes. J Diabetology 1: 4 .

90. Kamran MAA (2012) Targeting LDL Dyslipidemia for Controlling Progression of Nephropathy in Diabetic Population: A Cross Sectional Analytical Study. J Dow Univ Health Sci, Karachi 6: 7-11.

91. Chaturvedi N, Bandinelli S, Mangili R, Penno G, Rottiers RE, et al. (2001) Microalbuminuria in type 1 diabetes: rates, risk factors and glycemic threshold. Kidney Int 60: 219-227.

92. Mackin P, Macleod JM, New JP, Marshall SM (1996) Renal function in long-duration type I diabetes. Diabetes Care 19: 249-251.

93. [No authors listed] (1995) Effect of intensive therapy on the development and progression of diabetic nephropathy in the Diabetes Control and Complications Trial. The Diabetes Control and Complications (DCCT) Research Group. Kidney Int 47: 1703-1720.

94. Giorgino F, Laviola L, CavalloPerin P, Solnica B, Fuller J, et al. (2004) Factors associated with progression to macroalbuminuria in microalbuminuric type 1 diabetic patients: the EURODIAB prospective Complications Study. Diabetologia 47: 1020-1028.

95. Perkins BA, Ficociello LH, Silva KH, Finkelstein DM, Warram JH, et al. (2003) Regression of microalbuminuria in type 1 diabetes. N Engl J Med 348: 2285-2293

96. Costacou T, Ellis D, Fried L, Orchard TJ (2007) Sequence of progression of albuminuria and decreased GFR in persons with type 1 diabetes: a cohort study. Am J Kidney Dis 50: 721-732.

97. Svensson M, Nyström L, Schön S, Dahlquist G (2006) Age at onset of childhood-onset type 1 diabetes and the development of end-stage renal disease: a nationwide population-based study. Diabetes Care 29: 538-542.

98. Denke MA, Sempos CT, Grundy SM (1994) Excess body weight. An under-recognized contributor to dyslipidemia in white American women. Arch Intern Med 154: 401-410.

99. Sternfeld B, Sidney S, Jacobs DR Jr, Sadler MC, Haskell WL, et al. (1999) Seven-year changes in physical fitness, physical activity, and lipid profile in the CARDIA study. Coronary artery risk development in young adults. Ann Epidemiol 9: 25-33.

100. Folsom AR, Burke GL, Ballew C, Jacobs DR Jr, Haskell WL, et al. (1989) Relation of body fatness and its distribution to cardiovascular risk factors in young blacks and whites. The role of insulin. Am J Epidemiol 130: 911-924.
101. Haffner SM, Stern MP, Hazuda HP, Pugh J, Patterson JK (1987) Do upper-body and centralized adiposity measure different aspects of regional body-fat distribution? Relationship to non-insulin-dependent diabetes mellitus, lipids, and lipoproteins. Diabetes 36: 43-51.

102. Wood PD, Stefanick ML, Dreon DM, Frey-Hewitt B, Garay SC, et al. (1988) Changes in plasma lipids and lipoproteins in overweight men during weight loss through dieting as compared with exercise. N Engl J Med 319: 1173-1179.

103. Karvetti RL, Hakala P (1992) A seven-year follow-up of a weight reduction programme in Finnish primary health care. Eur J Clin Nutr 46: 743-752.

104. Seidell JC, Cigolini M, Deslypere JP, Charzewska J, Ellsinger BM, et al. (1991) Body fat distribution in relation to serum lipids and blood pressure in 38-year-old European men: the European fat distribution study. Atherosclerosis 86: 251-260.

105. Hu D, Hannah J, Gray RS, Jablonski KA, Henderson JA, et al. (2000) Effects of obesity and body fat distribution on lipids and lipoproteins in nondiabetic American Indians: The Strong Heart Study. Obes Res 8: 411-421.

106. Stamler R, Stamler J, Riedlinger WF, Algera G, Roberts RH (1978) Weight and blood pressure. Findings in hypertension screening of 1 million Americans. JAMA 240: 1607-1610.

107. MacMahon S, Cutler J, Brittain E, Higgins M (1987) Obesity and hypertension: epidemiological and clinical issues. Eur Heart J 8 Suppl B: 57-70.

108. Dyer AR, Elliott P (1989) The INTERSALT study: relations of body mass index to blood pressure. INTERSALT Co-operative Research Group. J Hum Hypertens 3: 299-308.

109. Bunker CH, Ukoli FA, Matthews KA, Kriska AM, Huston SL, et al. (1995) Weight threshold and blood pressure in a lean black population. Hypertension 26: 616-623.

110. Mufunda J, Mebrahtu G, Usman A, Nyarango P, Kosia A, et al. (2006) The prevalence of hypertension and its relationship with obesity: results from a national blood pressure survey in Eritrea. J Hum Hypertens 20: 59-65.

111. Sinaiko AR, Donahue RP, Jacobs DR Jr, Prineas RJ (1999) Relation of weight and rate of increase in weight during childhood and adolescence to body size, blood pressure, fasting insulin, and lipids in young adults. The Minneapolis Children's Blood Pressure Study. Circulation 99: 1471-1476.

112. Mamun AA, Lawlor DA, O'Callaghan MJ, Williams GM, Najman JM (2005) Effect of body mass index changes between ages 5 and 14 on blood pressure at age 14: findings from a birth cohort study. Hypertension 45: 1083-1087.

113. Brion MA, Ness AR, Davey Smith G, Leary SD (2007) Association between body composition and blood pressure in a contemporary cohort of 9-year-old children. J Hum Hypertens 21: 283-290.

114. Ni Mhurchu C, Rodgers A, Pan WH, Gu DF, Woodward M; Asia Pacific Cohort Studies Collaboration (2004) Body mass index and cardiovascular disease in the Asia-Pacific Region: an overview of 33 cohorts involving 310000 participants. Int J Epidemiol 33: 751-758.

115. Falaschetti E, Hingorani AD, Jones A, Charakida M, Finer N, et al. (2010) Adiposity and cardiovascular risk factors in a large contemporary population of pre-pubertal children. Eur Heart J 31: 3063-3072.

116. Spangler JG, Konen JC (1996) Hypertension, hyperlipidemia, and abdominal obesity and the development of microalbuminuria in patients with non-insulin-dependent diabetes mellitus. J Am Board Fam Pract 9: $1-6$.

117. Metcalf P, Baker J, Scott A, Wild C, Scragg R, et al. (1992) Albuminuria in people at least 40 years old: effect of obesity, hypertension, and hyperlipidemia. Clin Chem 38: 1802-1808.

118. [No authors listed] (1980) WHO Expert Committee on Diabetes Mellitus: second report. World Health Organ Tech Rep Ser 646: 1-80.

119. Mensing C, Boucher J, Cypress M, Weinger K, Mulcahy K, et al. (2000) National standards for diabetes self-management education. Diabetes Care 23: 682-689. 
Citation: Aziz KMA (2014) Association of Microalbuminuria with Ischemic Heart Disease, Dyslipidemia and Obesity among Diabetic Patients: Experience from 5 Year Follow up Study of 1415 Patients. Bioenergetics 3: 118. doi: 10.4172/2167-7662.1000118

Page 10 of 10

120. Aziz KM (2012) Management of type-1 and type-2 diabetes by insulin injections in diabetology clinics - a scientific research review. Recent Pat Endocr Metab Immune Drug Discov 6: 148-170.

121. Nathan DM, Buse JB, Davidson MB, Ferrannini E, Holman RR, et al. (2009) Medical management of hyperglycemia in type 2 diabetes: a consensus algorithm for the initiation and adjustment of therapy: a consensus statement of the American Diabetes Association and the European Association for the Study of Diabetes. Diabetes Care 32: 193-203. 